\title{
Still Looking
}

\section{Self-Love, Ethics, and Seeing Jewish}

\section{Laura Levitt}

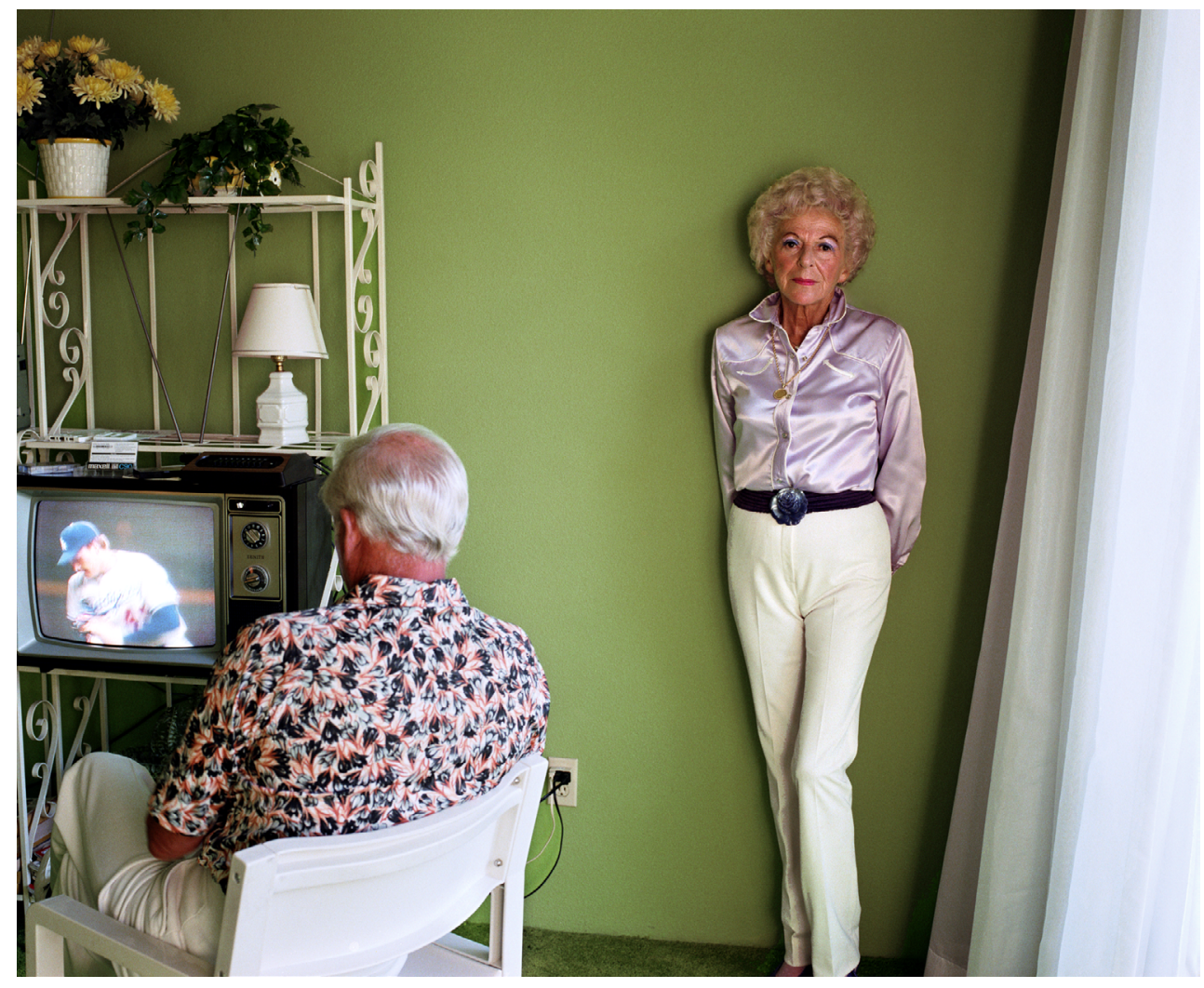

In memory of Larry Sultan

\section{A View from Afar}

\section{The Civil Contract of Photography}

In her monumental study, The Civil Contract of Photography (2008), Israeli cultural theorist Ariella Azoulay looks at images of physical violation and the destruction of property in press photographs, art photographs, and most powerfully the recirculation of newspaper images in artistic works coming out of the Second Intifada. As she explains, all of these photographs need to be viewed repeatedly; still images need to be watched as moving pictures are screened. Instead of the projector creating the illusion of movement, she insists that viewers must return to still images again and again. Over time and in different geographical and/or physical con- 
texts, she argues, we give life to what are otherwise set or static pictures. These animating efforts themselves allow us to appreciate the potential of photography as an ethical and civil practice. Through these efforts to look carefully we become a part of a network of relationships: ethical relationships between viewers, photographers, and those who are photographed. These relationships are what constitute what she calls the "civil contract of photography." This engaged notion of photography echoes, in a different key, critical theorist Kaja Silverman's insistence on "the paradigmatic status" of aesthetic works, especially photography, to guide us in what she calls "the arts of love and productive looking" (1996:5).

Even as they focus on different moments in the process of engaging with photography, both Silverman and Azoulay see this potential at the heart of photography. In her work, Azoulay addresses the creation and recirculation of the photograph to present this contract as an alternative to notions of modern citizenship. She writes about the ephemeral yet pervasive social connections established and reestablished in taking photographs, insisting that those involved in these efforts always perform in relation to each other. They know their roles within this threeway relationship (2008). Azoulay uses this alternative contract as leverage against those created by civil authorities and nation-states. In place of such laws she deploys photography as a different form of civil engagement, systematically interrogating the ways in which nation-states use citizenship to limit or circumscribe such civil acts of engagement, acts that must and necessarily do cross borders and boundaries of various kinds. For her, photography offers an alternative to the kind of us-them distinctions imposed by nation-states that disallow precisely the kinds of intimacy and social engagement she sees in photography. Silverman instead asks us to consider what happens as these already established images circulate and recirculate. And it is in this recirculation that Azoulay and Silverman's approaches come together.

The civil contract of photography is Azoulay's way into a sustained engagement with the visual legacy of the Second Intifada, the case study at the heart of her text. It is when she revisits these images as they are reappropriated by various contemporary artists to create new works that Azoulay enacts what Silverman describes as our ability to "retroactively revise and revalue" images. As Silverman explains, "We can look at an object a second time, through different representational parameters, and painstakingly reverse the process through which we have arrogated to ourselves what does not belong to us, or displaced onto another what we do not want to recognize in ourselves" (1996:3). Both Azoulay and Silverman also make clear that these engagements have limited utility unless they are repeated. In Silverman's words: "Although such re-viewing can have only a limited efficacy, and must be repeated with each new visual perception, it is a necessary step in the coming of the subject to an ethical or nonviolent relation to the other" (3).

I begin with Azoulay and Silverman because of what they say about the need to watch still images. But I also do so because of the power of the kinds of relationships that are created through photography and its ongoing circulation. These insights suggest the larger stakes involved in a performative notion of photography. Moreover, by returning anew to images and

Figure 1. (facing page) Larry Sultan, My Mother Posing for Me, 1984; color photograph, $30 \times 40$ inches. (Courtesy of the Estate of Larry Sultan)

Laura Levitt is a Professor of Religion, Jewish Studies, and Gender at Temple University where she directs the Women's Studies Program. She is the author of American Jewish Loss after the Holocaust (NYU Press, 2007) and Jews and Feminism: The Ambivalent Search for Home (Routledge, 1997). Her recent publications include: "Returning to the United States Holocaust Memorial Museum: The Tower of Faces Ten Years Later," in Photographs, Histories, Meanings (Palgrave, 2009) and "Love the One You're With," in The Passionate Torah: Sex and Judaism (NYU Press, 2009). Her current project, "Evidence as Archive" looks at criminal evidence held in police storage as a repository of memory. llevitt@temple.edu 
critical works on photography - images of American Jewish life, works that have spoken powerfully to me in the past - through the lens of Azoulay's work, I want to shed new light on those images. I now want to draw connections between self-love and ethics. In other words, I use Azoulay's civic contract and her insistence on the importance of returning to photographic images again and again to reconsider Larry Sultan's Pictures from Home, Cindy Sherman's Untitled Film Stills, and a photograph of my own to draw connections between the kind of civility Azoulay argues for and the form of ethical looking that drew me to Silverman's work in the first place. This essay is, in a sense, an enactment of the kind of watching or revisiting that both Azoulay and Silverman call for. My previous and repeated encounters with images that have touched me - those of Sherman and Sultan - have led me to rethink what it means to perform as an American Jewish woman. By placing Azoulay in conversation with Silverman as I return to images close to home, I hope to better appreciate how American Jews look at ourselves and how that seeing enables us to more fully engage with others, including those depicted in Azoulay's arresting study.

\section{Pictures from Home}

Photographer Larry Sultan's 1992 book Pictures from Home brings together 10 years of photographs he took of his aging parents in their various homes. But it is more than this. Alongside these lush contemporary photographs that depict the almost surreal colors of southern California suburban life, he includes re-photographed family images - images originally from home movies made by his father, now dreamy still images - as well as a multivocal narrative of the family's story, told in three separate typefaces to signify the distinct voices of father, mother, and son. As Sultan explains, this project began in 1982 on a visit to his parents in Los Angeles:

One night, instead of renting videotapes, we pulled out the box of home movies that none of us had seen in years. Sitting in the living room, we watched thirty years of folktales - epic celebrations of the family. They were remarkable, more like a record of hopes and fantasies than of actual events. It was as if my parents had projected their dreams onto film emulsion. (1992:18)

In his mid-30s at the time, "longing for the intimacy, security, and comfort" that he associated with home, Sultan thought he was making a portrait of his father, but this time reversing the roles. As he explained, "[L]ike a parent with an infant, I would observe him knowing that I would not be observed myself" (18). He thought he would chronicle his father's fate in corporate America; tell a broader story about what happens when "we are driven by images of success." He was going to puncture the mythology of the American family and was willing to use his own family to prove his point. But this is not quite how it turned out. Instead of maintaining this distance, he found himself ever closer to the work he was doing, finding that in photographing his parents he was doing something else. "What drives me to continue this work is difficult to name, it has more to do with love than with sociology, with being a subject in the drama rather than a witness" (18).

Sultan's act of love, his willingness to make himself a part of this book, to enter into the pictures, is an explicit acknowledgment of the kind of intimacy about which Azoulay and Silverman write. Sultan places himself in the triangular relationship between the photographer, those being photographed, and the viewer. We come home with him. And home is where I see his family's American Jewishness performed.

Jewishness is not presented here as explicit rituals but through the intimacies of a kind of familial looking (Hirsch 1997, 1999). There are traces of a more explicit Jewish story in the various narratives presented in Sultan's book, but what stopped me in my tracks when I first saw these images was something else, something more subtle. I saw my own family, our vulnerabilities, our efforts to live out the American dream, in his photographs. This intimate famil- 
ial vulnerability made me read these images as Jewish. ${ }^{1}$ I saw my grandmother in his mother. This was not so much a nostalgic looking but something else, a queasy discomfort. It was the sadness amidst the seeming abundance that touched me.

Having lived with Sultan's work for many years, I am keenly aware of how, over time, I continue to see and experience different things with each viewing. Certain aspects of this work speak to me now with a kind of urgency that I had not appreciated at an earlier moment. When I first began writing about Pictures from Home in the late 1990s I thought that this work rehearsed an argument I have made elsewhere about a kind of Jewish excess played out through accessorizing - clothing and décor, the elaborate colorcoordinated walls, furniture fabrics, and tabletop decorations (Levitt 2000). I wanted to pin the familiarity of this work, its Jewishness, on this excess. This was my way into Sultan's work, but over time, I began to find that analysis fell flat. The ironic distance that generally

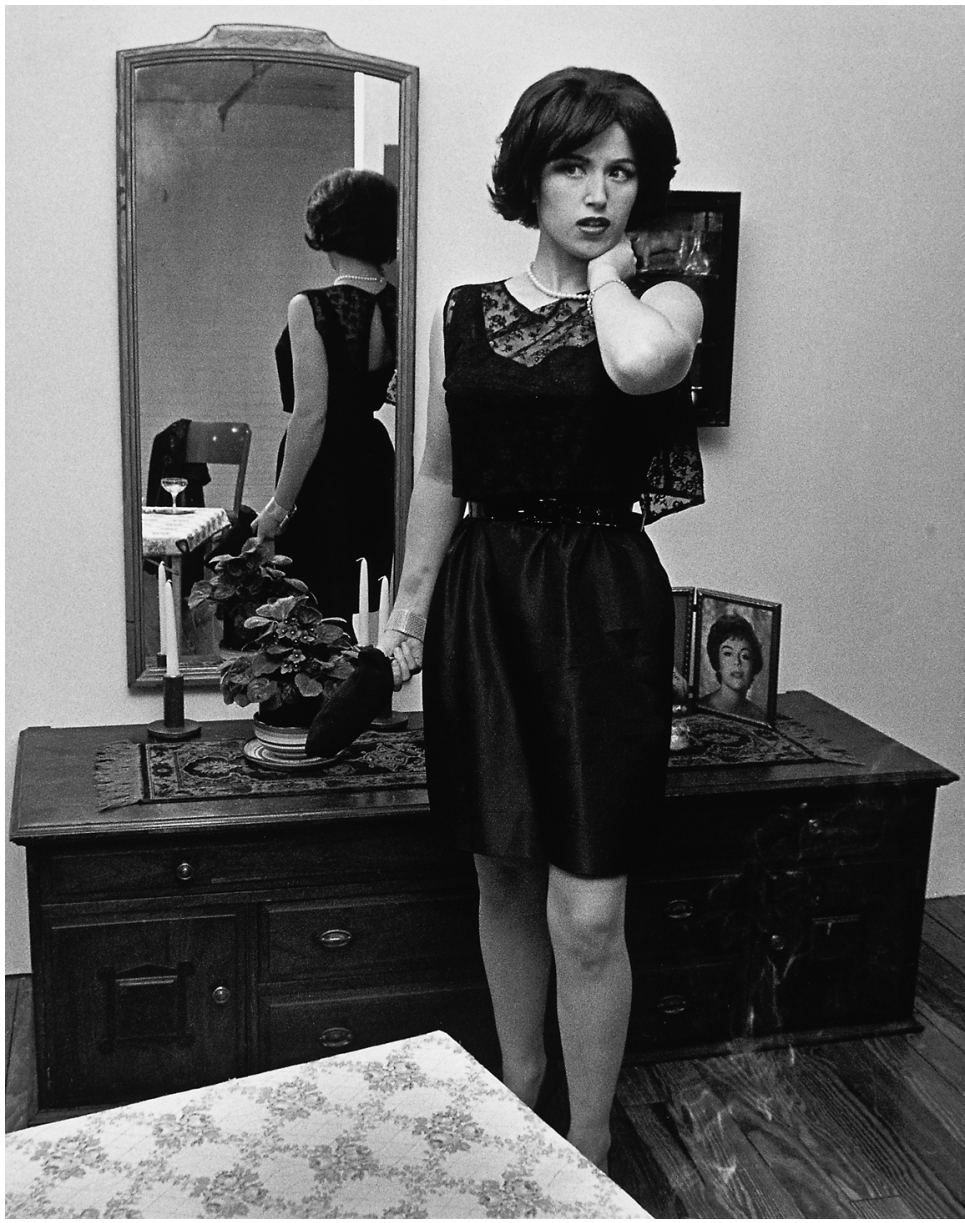

Figure 2. Cindy Sherman, Untitled Film Still, 1978; black and white photograph, $10 \times 8$ inches. (Courtesy of the artist and Metro Pictures) comes to explain these data as Jewish $^{2}$ felt alienating and no longer spoke to the allure of his pictures. And so I reconsidered my attraction to Sultan's work by thinking about it in relation to Silverman's account of Cindy Sherman's Untitled Film Stills. ${ }^{3}$ In what follows I return to that analysis to draw further connections between Silverman's work, Sultan's images, and the kinds of ethical concerns raised by Azoulay in a very different context. By identifying a "good enough" American Jewish position in the ways Silverman suggests, I draw connections between self-love and our ability to see others and ourselves more ethically.

1. To be clear, this is a particular Jewish vision, a dominant but not exclusive vision of Eastern European, Ashkenazi Jews, the vast majority of American Jews whose families came to the US at the turn of the last century. There are other ways of performing American Jewish identity (see Chevlowe 2005).

2. Here I am thinking of the ironic distance that animated Norman Kleeblatt's exhibit and the catalogue Too Jewish (1996).

3. I presented various versions of this material at two conferences: the Hawaii International Conference Arts and Humanities (2006) and at the American Studies Association (2004). 


\section{Through a Gendered Lens}

In writing about Cindy Sherman's Untitled Film Stills Kaja Silverman has argued:

We are not invited to laugh, either at the aspirations of the figures in them to be apprehended in idealizing ways, or about the generally doomed nature of that undertaking. Rather we are encouraged to recognize ourselves in the Untitled Film Stills. The tenderness with which Sherman details her protagonists' narcissistic ambitions and the fact that she literally puts herself in their place [...] encourages us to identify with them. (1996:224)

Silverman insists that the power and allure of these images is not their ironic distance, ${ }^{4}$ the ways they help us see the absurdity of these women's efforts to approximate cultural ideals always already out of their reach. Although it is possible to look at these images and laugh, such laughter is beside the point. What they offer instead is something less comfortable and more compelling; they demand that we see ourselves in these women, in their efforts and their striving. And like Sherman, who performatively becomes each of these women, playing them in each and every shot, we too can enter the frame. What this requires, according to Silverman, is an affective engagement - "tenderness" (1996:224). Sherman does not distance herself from these women and their efforts; she takes on these longings and makes them her own. In this way tenderness is not only an affective clue as to how the photographer approaches her subjects but a challenge to her audience. We too are asked to look lovingly at these women and their efforts. Here the contract is more truncated. Sherman is both the photographer and the photographed subject, albeit playing a series of roles, and in both these positions she engages with us her audience. At stake are the ethical relationships Sherman has with the personas she embodies and the photographs on the one hand, and the relationship viewers have with all of these women on the other.

Although these poses are utterly familiar, common, a part of a vast repertoire of all-toofamiliar cultural ideals, it is their very triteness that calls our attention to them. By stilling these restless and relentless desires, Sherman's stills help us see these all-too-familiar performances - model and movie-star pinup poses of sexy and alluring women - with new eyes.

As Silverman suggests, these images ask us, in this case women, to stop our normal processes of assimilating such images. They arrest us. They stop us in our tracks, as we ourselves are just about to perform these all-too-common gestures. The images make us pause. And in so doing, they help us begin to see what it is that we normally do and to perhaps begin to do something different. They stop time. These are, after all, stills — single moments in an ongoing stream of images, poses, postures, enactments that we repeat daily. Because Sherman stills the rush of these images, she allows us to take another look, to return to familiar patterns and see them in their component parts and, in so doing, begin to appreciate these performances from a different angle. She urges us to move outside of the teleological trajectory of having to take on cultural ideals where the ideal as goal defines a linear trajectory. Instead Sherman lets us engage with the stills as objects in and of themselves, objects outside this linear narrative that always already assumes the ideal. And here Sherman's project is especially telling. After all, the whole conceit is that these are "film stills" when, in point of fact, there is no film outside of the filmy everyday enactments of these efforts to approximate cultural ideals in which we, as well as the protagonists in these stills, are always already engaged.

\footnotetext{
4. Silverman explains, "Other critics have also sensed that The Untitled Film Stills make available to us more than one viewing position, but this alternative viewing position is generally assumed to involve ironic detachment from the women and their poses" (223-24). After presenting a few of these positions, she argues "with Peter Schjeldahl that there is 'an absence of any reassuring, campy wink or nudge' in these images" (224).
} 


\section{Sultan's Stills, Good Enough}

Like Sherman, Sultan, in Pictures from Home, slows down the rush of images to offer a tender portrayal of his parents, his family, and the lives they led. And not unlike Sherman, he too is very much a part of these pictures. Instead of posing as his parents, he attempts to take his father's place as family photographer, behind the camera. ${ }^{5}$ He returns home to photograph and re-photograph what his father saw and what his father created through the lenses of his cameras, both moving and still. But, unlike Sherman, Sultan returns to actual projections, the literal stream of home movies his father took of his family, painstakingly making from this stream a range of lush, literal stills.

Silverman's reading of Sherman's stills clarifies what is at stake for me in identifying with these women or with Sultan's parents and their homes. After presenting Sherman's tender approach to her protagonists' "narcissistic ambitions," Silverman goes on to argue that when we begin to identify with these women, what we identify with is not their "ideal imagos"; we do not connect so much to what they strive to become, but rather with what they do in the instance. As Silverman explains, "It is rather with the women themselves, in all their manifest distance from the mirror, that we are encouraged to form this psychic alignment" (1996:224). Again what this means is that we are not connecting to the ideals they are attempting to reach, but to their momentary strivings in and of themselves. As we return to the stills again and again, we are reminded that there is no chance of reaching the ideal. There is no linear film narrative. There are only these still images. Actually, Silverman is emphatic about this. She writes, "The case needs to be stated even more forcefully: it is because the protagonists of the Untitled Film Stills are shown to fall so far short of approximating their ideal imagos that we identify with them" (224). This falling short is what becomes familiar.

According to Silverman, as we are exposed to these efforts, these gestures as depicted in the Sherman stills, we become conscious of the often less-than-conscious efforts that we ourselves regularly participate in as we attempt to form versions of ourselves, versions that are meant to conform to cultural ideals always outside of our reach. To look ethically, to be able to touch our own investment in these efforts, works like Sultan's and Sherman's are crucial. They help us imagine other ways of looking that might take us out of the binary of ideality and abjection. And, as Silverman powerfully argues, it is through the mirroring of these images, images that are not ours, that we not only learn to love abjected others but also ourselves.

So, I want to ask, what happens if instead of irony and distance, we provisionally confer a kind of ideality upon these bodies as "good enough"? In other words, what happens if we use Silverman's insights to look more tenderly at precisely these American Jewish bodies, Sultan's parents, whose very excessive efforts to accessorize mark their inability to ever approximate the American cultural ideals they so long to embody but cannot? What happens if we begin to see them as "good enough" Jews?

Seeing Sultan's parents in this way allows us to stop precisely the filmy repeated projection of a certain Jewishly-inflected American script of social success not only onto Larry Sultan's parents but also onto our own parents, grandparents, and ultimately ourselves. I say this because Sultan's work has stopped me in my tracks. And this arrested gaze, according to Silverman, is the beginning of a more ethical way of looking. As she explains, to live the ideal in the mode of "the good enough" is a paradigm through which ideals can be simultaneously lived and deconstructed. A good enough stance helps us dissolve our ideals into the tropes that make them seem whole, and instead, more fully grasp their fundamentally figural status (4).

5. This is exactly what Sultan was getting at as he compared his project with Raymond Carver's short story "Cathedral" in his informal gallery talk at Dartmouth College during the "Familial Gaze" conference (Sultan 1996; see also Hirsch 1999 and Levitt 2000). 
As Silverman explains, aesthetic works of visual culture, photographs like Sultan's and Sherman's, allow us access to some of the unconscious mechanisms that inform how we see ourselves through this idealizing process. In so doing, these aesthetic works can "enormously expand our libidinal capacities" (5). As we identify with Sherman's women and Sultan's parents, we begin to participate in what Silverman calls, "the arts of love and productive looking" (4).

\section{A View from Home}

\section{Another Look at Self-Love}

As in performativity, repetition is crucial to producing cultural norms and ideals. By noticing the repetition, we begin to still the rush of the often less-than-conscious enactments of these norms. By slowing down we start to see this process that is otherwise in motion and, as such, invisible.

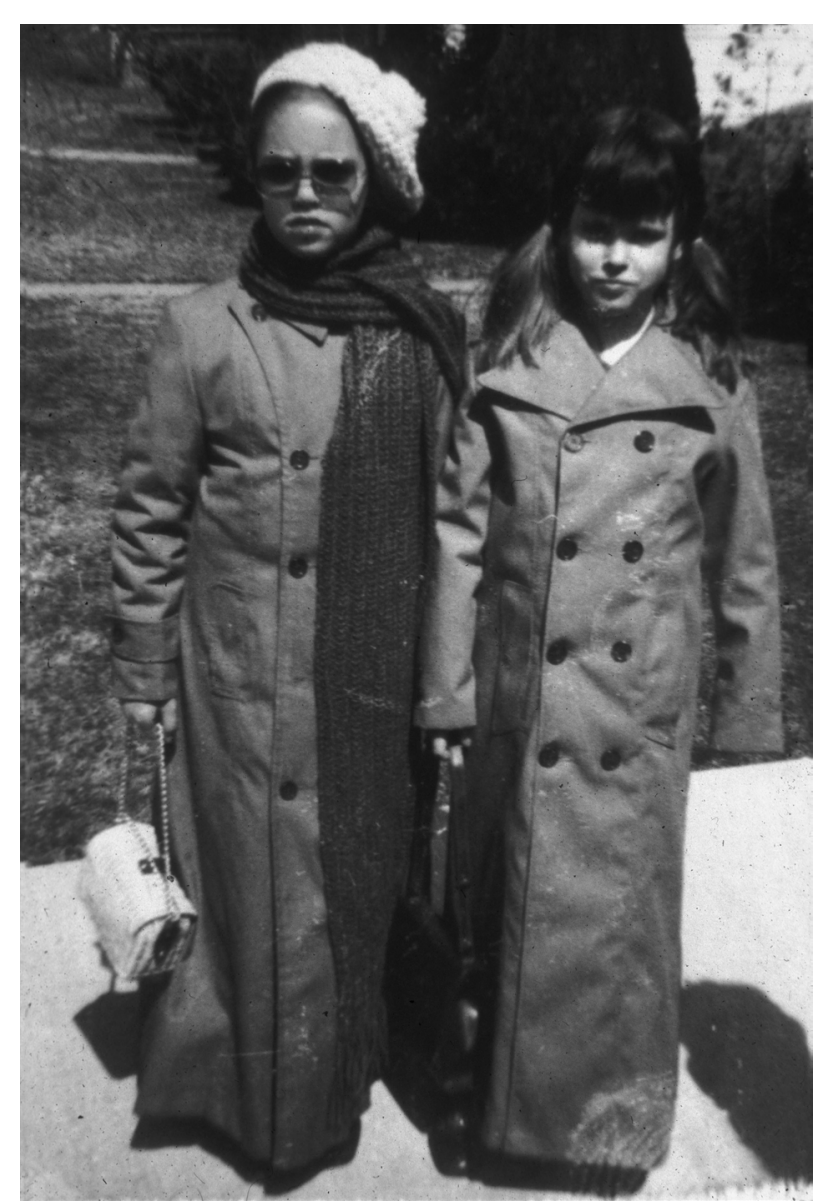

Figure 3. Polaroid snapshot, Levitt family collection, circa 1971. (Courtesy of Laura Levitt)
My initial engagement with Sultan and Sherman's work reminded me of a childhood image of my own, a poor quality Polaroid picture of me with a friend dressed up in our new maxi coats, circa 1971, a fashion statement of great sophistication. And, although I have addressed this image before (Levitt 1998), I return to look at it again through Silverman's mirror here. I do this in order to stop my own automatic reaction, the ease with which I already know how to see this image as simply ironic. The problem is that like Sherman's protagonists, the little girl in this picture is not winking at the camera. She is not at all distant or ironic in her posing and her posture. She is wearing this costume and assuming this position precisely because she wants to be seen in all of her 11-year-old sophistication.

What I know is that I wanted to look really cool. I wanted to be "the really real," a girl just like the little girls depicted in the advertisements in the New York Times Sunday editions that were delivered to our home in

the hinterlands of Dover, Delaware. I too wanted to be able to wear the latest fashions and, by accessorizing, become the height of stylish sophistication. And yet, returning to this image again with Silverman, I begin to appreciate how difficult it is for me even now to love this little girl who is trying so hard. Irony was so much more satisfying. It meant that I could avoid my visceral embarrassment, shame, and sadness at my own excessive effort to approximate for me what was indeed a cultural ideal. 
To keep avoiding precisely this more difficult labor on another occasion, I found myself attracted to the less-studied child, the little girl who seemingly does not even bother to try to be sophisticated. I wanted to be her. In this longing she came to embody a different ideal. By making fun of my child self's efforts at trying too hard, I wanted to see the other little girl as my alternative, as what the little girl I once was could not inhabit despite her enormous effort: normal. And yet that position was never who she/I had wanted to be. She never wanted to be seen as just a little girl, a regular little girl like her friend in the picture. She/I instead wanted to be the ideal, a fashion plate. Nevertheless, I have to admit that I have felt relief when colleagues, friends, and students who know me now thought I was the less-studied little girl when I showed them the photograph.

As I return to this picture now, I know that that stance was not one I could honestly inhabit. Although I am still uncomfortable and perhaps even ashamed of this picture, Sultan's and Sherman's images have helped me recognize something about my own efforts to look a certain way. I find myself in the studied efforts of both the women in Sherman's stills and in Sultan's parents. I recognize something about myself in these efforts that I see so vividly and lovingly re-depicted in both Cindy Sherman's Untitled Film Stills and Larry Sultan's Pictures from Home images and text. And although I do not believe that these efforts are essentially or in any way innately or exclusively Jewish, I do think that they speak powerfully to a pervasive way that many mid- to late-20th-century American Jews performed their Jewishness by trying very hard to approximate ideals that, in the end, always eluded us, in this case, images of an upwardly mobile middle-class American success story, beautifully furnished homes, stylishly attired bodies.

\section{A Postscript}

\section{"Love Thy Neighbor as Thy Self"}

Reframing these reflections in light of both Azoulay's and Silverman's work, I feel a different kind of discomfort. For so many American Jews, the seemingly petty, ordinary concerns I address here-Ashkenazi, middle-class American ideals, being comfortable and at home in America - feel inauthentic, not nearly good enough. As performances of Jewishness, they pale in comparison to the urgency of either an earlier 20th-century traumatic European Jewish past, or the political concerns of contemporary Israel. I feel the pull of these claims. And so, purposely, I have turned to Azoulay's work to try to challenge these all-too-familiar reactions. The connections I am drawing are both formal and ethical. Azoulay, like Silverman, insists on an ethics of looking. Both write about civility and tenderness in ways that resonate with the love that Sultan wrote about photographing his aging parents. And yet for Azoulay, the stakes are seemingly so much higher. She is, after all writing about images of Palestinians in the Israeli press during the Second Intifada, images indeed of abjected others who plead to be seen as human beings whose homes and livelihoods are being destroyed. Azoulay insists they be seen more humanely in this particularly charged and violent political context. These images demand to be watched. And with the help of Azoulay and the contemporary Israeli and Palestinian artists she writes about who create works of art from violent images of occupation, we see what was not fully visible when those images first appeared in the Israeli press.

I do not want to lose sight of this difference or the urgency of those images. Rather I want to draw some connections and some important distinctions that I believe may enable us to see them more powerfully. I do not think it is possible to fully appreciate what Azoulay is arguing for in her work without a strong sense of context. From where is one looking at these images of the Intifada? How do we position ourselves? More pointedly how do American Jews view images from Israel and Palestine? In what ways do these images speak to us and signify Jewish? And how do those visions of Jewishness relate to our own more quotidian pictures of ourselves, images like Sultan's and my childhood snapshot? By owning these American Jewish positions, we might not require that those images from afar stand in for a kind of authenticity we cannot claim for ourselves. 
Without confronting the kinds of intimate desires that shape the ways we look at ourselves here as American Jews, we cannot critically engage with the images Azoulay presents. The kinds of affective engagement that Sultan and Sherman enable demand that we account for ourselves. As such, they allow us to more fully engage with images of others as well as ourselves. They force us to do this work from home as American Jews living in the US in the present. They demand that we own these seemingly ordinary stances as Jewish positions and that we refuse to defer to some other more authentic Jewish cultural ideal to speak or see as Jews. Without this kind of self-reflection and claiming, indeed self-love, we cannot begin to appreciate images from Israel and Palestine like those addressed by Azoulay. Knowing that we come to these images from somewhere and that they do not in any simple way speak for us, can help us better see those depicted in them.

For American Jews, a serious reckoning with our own desires for authenticity and an acceptance of our good-enough American Jewish positions, as opposed to Israel or the Holocaust or Orthodoxy as more real Jewish cultural ideals, can help us, in this case, to resist conflating Israel in any simple way with Jewishness. Although "Israel" and "Jewish" are not one and the same thing, we can make connections. Nevertheless, the distinction I am insisting on here enables us to appreciate the available range of Jewish positions, including our own as Jewish. And I am arguing that all of these positions are legitimate. Only by owning these most intimate desires for belonging and authenticity, posed not only by dominant cultural ideals but also by forms of Jewishness that are manifested elsewhere, in this case in Israel, ${ }^{6}$ can we more fully see and appreciate the connections and the differences between those Jewish images and those Jewish positions, and our own.

Part of what I am arguing is that we are attracted to and, in this case, disturbed by the photographs Azoulay presents because we have not owned, in Silverman's terms, our own "good enough" American Jewish positions. When we make Israel into the really real Jewish, we lose perspective. We no longer appreciate the distance that animates our longing for precisely these kinds of singular versions of authenticity before whom we always fall short.

And yet, there is more that connects these efforts, as Azoulay suggests. It is only by engaging in a practice of what she calls "watching" photographs that we can begin to appreciate their potentially transformative power. Watching is all about looking again and again and echoes both Silverman's account of the film stills and my reading of Sultan's work and my own photograph.

All of these efforts are profoundly interrelated. Without being able to love and accept ourselves we are less open to others. This is not an either/or proposition. To be able to engage in the kind of civility for which Azoulay calls, or the kind of productive looking that Silverman describes, we must be able to look sympathetically at both ourselves and at others. The biblical injunction to "love thy neighbor as thy self" requires an acceptance of Silverman's "good enough" self. It is this self who, in turn, can begin to appreciate the vulnerabilities of others. And so, in search of the kinds of tenderness and civility that are the promise of photography, I find myself still looking.

\section{References}

Azoulay, Ariella. 2008. The Civil Contract of Photography. New York: Zone Books.

Chevlowe, Susan, ed. 2005. The fewish Identity Project: New American Photography. New Haven: Yale University Press.

Hirsch, Marianne. 1997. Family Frames: Photography, Narrative, and Postmemory. Cambridge, MA: Harvard University Press.

6. This could be the Holocaust or Orthodoxy, as well. What interests me is the positing of a Jewish cultural ideal that feels distant from us, from our everyday lives, and then the idea that we can use this, not unlike the ideals of femininity that are always already out of reach in Sherman's stills. 
Hirsch, Marianne, ed. 1999. The Familial Gaze. Hanover: University of New England Press.

Kleeblatt, Norman, ed. 1996. Too fewish: Challenging Traditional Identities. New Brunswick: Rutgers University Press.

Levitt, Laura. 1998. "Passing through the Family Photograph.” Unpublished conference paper.

Levitt, Laura. 2000. "Picturing American Jews: Seeing American Jewish Life.” In Mapping Fewish Identities, ed. Laurence Silberstein, 65-95. New York: New York University Press.

Silverman, Kaja. 1996. Threshold of the Visible World. New York: Routledge.

Sultan, Larry. 1992. Pictures from Home. New York: Harry Abrams.

Sultan, Larry. 1996. Gallery talk, Dartmouth College, Hanover, NH. 